\title{
Teaching Chinese Culture in College English Classes in the Context of Outreaching Strategy
}

\author{
Xiaomei Zhu \\ Sino-German Institute of Design and Communication, Wanli University, Zhejiang, China
}

\begin{abstract}
Although a consensus has been reached internationally on the importance of teaching home culture in foreign language education, this is still debated in China. By ignoring cultural factors, some regard English as simply a tool and believe linguistic skills to be the core of English teaching, especially in teaching English to non-English major students. Most, on the other hand, have recognized the intertwined relationship between language and culture, thus support intercultural language teaching. As Byram (1997) notes that both home culture and target culture are parts of the knowledge an "intercultural speaker" should possess. In spite of the growing emphasis that has been placed on intercultural communication competence (ICC) by policy makers in the context of "Chinese Culture Going Global Strategy", it is neglected in practice and is still in secondary status. This phenomenon is especially widespread in integrating Chinese culture into college English courses and there are many problems and challenges in its implementing. Therefore, after discussing the rationales of involving Chinese culture in teaching college English, some suggestions are provided.
\end{abstract}

Index Terms-College English teaching, outreaching strategy, intercultural communication

\section{INTRODUCTION}

Since the beginning of the new millennium, China has been playing an increasingly important role in the world economy, and more recently, the Chinese government has started to devote more resources to increasing Chinese cultural influence. This can be seen through national policies such as the "Chinese Culture Going Global Strategy" (Yang, 2014). However, the development of "cultural China" has far lagged behind the economic China or political China (X. Wang, 2018, p125). The Chinese government has realized this, and has taken efforts to disseminate Chinese culture and shape the national image for political and economic purposes. The spread of Confucius Institutes around the world serves as a good example. Under the background of Outreaching Strategy to keeping cultural confidence in globalization, English teaching has become a key issue and questions about identity, culture, status of English and course design are raised.

The status of English in China has always been a contested issue (Gil \& Adamson, 2011). The fundamental contestation of English teaching in China lies in different objectives of learning a foreign language, notably the two conflicting objectives of learning a foreign language from different perspectives. One is from the utilitarian angle which sees language as a technical tool for communication. Cai $(2017,2018)$ is a strong advocate of this view. The other views English education as both instrumental and humanistic; therefore, it is more than a language training programme but an indispensable part of General Education. Its purpose is to improve student competence not only in interlingual but also intercultural communication (S. R. Wang, 2011, 2016). Still, there are educators who interpret ELT (English language teaching) from political and sociocultural point of view (Feng, 2009, 2011, 2015), which depict language teaching in a much deeper and broader context.

Based on different understandings of language leaning purposes, educators have developed various theories and proposed diverse English course designs, some of which conflict with each other. Nevertheless, most accept that language is far more than just a tool, as Gadamer (1976) notes language is fundamentally a "social, cultural and historical phenomenon" (cited in Liddicoat \& Scarino, 2013, p15). In teaching or learning a language, issues like culture and identity are unavoidable. However, this is not unanimously agreed in China. In spite of the growing importance put on intercultural language teaching by policy makers, it is neglected in practice. Therefore, the focus of this paper is on discussing the rationale of integrating Chinese culture in College English courses and proposing some suggestions of implementation.

\section{LITERATURE REVIEW}

\section{A. Culture and Language}

The complex term of culture involves aspects from the "anthropological" view (ways of life, values, beliefs); as well as from humanistic view (arts and media) (King, 1997). However, the dichotomy between practice system and symbol system of culture is not helpful in language teaching and learning as it "divides meaning and action" (Liddicoat \& Scarino, 2013: 22). Sewell (1999) states that these two systems are not contradictory but complementary. And "to engage in cultural practice means utilizing existing cultural symbols to accomplish some end" (p. 47). 
Therefore, in language learning, the understanding of culture as a united system of the two is essential and it requires going beyond a view of culture as a body of static knowledge about any specific society (Liddicoat \& Scarino, 2013). The relationship between language and culture according to Fishman (cited in C. Baker, 2011: 59) is, on one hand, a langue indexes and symbolizes its culture; on the other hand, culture is partly created from its language. Accordingly, the closely intertwined nature between culture and language, as W. Baker (2012) puts it, makes it hard to "teach language without an acknowledgement of the cultural context in which it is used" (p. 62).

In spite of the close inner connection between culture and language, "it is possible for someone to have high proficiency in two languages but be relatively monocultural" (Baker \& Wright, 2017:16), as in some cases of foreign language graduates. This shows it's relatively easy to master a language linguistically, however, to "act interculturally" is more demanding (Feng, 2009).

W. Baker (2012) argues that effective communication need not only technical skills of a language (English) such as syntax, lexis or phonology, the "ability to make use of linguistic and other communicative resources" in various contexts and relationships are of the same importance (p. 63). He goes on to maintain that no language can be culturally neutral, not even a lingua franca. Since the function of language is for communication, it bounds to include the key elements of "people, place and purpose". None of these "may exist in a cultural vacuum" (p. 64).

Liddicoat \& Scarino (2013) demonstrates the interrelationships between language and culture in communication in a diagram which presents "the language-culture interface as a continuum" (p. 26).

TABLE I.

INTERCULTURAL LANAGUAGE TEACHING AND LEARNING LIDDICOAT \& SCARINO (2013)

\begin{tabular}{cccc}
\hline Culture most apparent & $\leftarrow$ & Pragmatic norms & Norms of interaction \\
\hline World knowledge & Spoken/written genres & Norms of linguistic form \\
Culture as context & $\begin{array}{c}\Downarrow \\
\text { Culture in general text }\end{array}$ & $\begin{array}{c}\text { Culture in the meaning of } \\
\text { structure }\end{array}$ & $\begin{array}{c}\text { Culture in the positioning } \\
\text { of units of language }\end{array}$ \\
\hline
\end{tabular}

This figure shows the intertwined relationship between language and culture from macroscopic aspect including world knowledge, where culture is the focus, to microscopic aspect of linguistic, where language is the focus, in the continuum. Despite the variety of the appearances, language and culture are both "integrally involved across the continuum" (p. 26).

This depiction of relationship between language and culture demonstrates the essence of teaching and learning a language --- culture exchange, which is some sort of consensus reached among educators (Byram, 1997; Gudykunst, 2004; Holliday, 2009; Feng, 2007, 2009).

\section{B. Culture, Language and Identity}

As to the relationship between language and identity, Baker \& Wright (2017) believe in forming the identity of a group, region culture or nation, language is "one of the strongest symbols and boundary markers" (p. 469). In other words, language is "an index, symbol and marker" of identity (p. 66).

Garcia (2009) also believes the function of language is more than just "semiotic or symbolic"; it is also "rhetorical", "used to discursively construct identity and solidarity" (p. 82). This identity function becomes essential in the encountering of people from different linguistic and cultural background in the process of globalization and in, on a larger scale, language teaching and learning. Postcolonial identity involves not only "sameness" but by extension "otherness" and the development of hybrid identities which involve plural language practices (p. 83).

Liddicoat and Scarino (2013) describe the challenges of identity posed by language learning in two questions: first "who am I when I speak this language?" and second "how am I when I speak this language?" (p. 23) Their intension is to emphasize the complexity of culture and individual's relationships with culture. When learning a language, an individual is exposed to the encountering of cultural exchanges between home and target culture individually. This is when, in some cases, cultural identity is challenged. For example, will a Chinese learner of English doubt about his/her identity in the intercultural language learning?

Baker \& Wright (2017) discuss the intertwined relationships of language, culture and identity in explaining the dynamic of an individual's identity. They state that the individual's identity is "not fixed, given or unitary", because it is socially generated and developed by the using of language and "intentional negotiation of meanings and understandings", namely, culture (P. 469).

Gudykunst (2004) defines this cultural identity as "our social identities that focus on our membership in our cultures" (p. 66). Thus, this interrelationship among language, culture and identity makes learning a new language and culture more complex than just add more linguistic and cultural resources to an individual's repertoire. Though this knowledge may generate new possibilities and broaden the learners' vision, it also "creates a need for mediation between languages and cultures and the identities that they frame" (Liddicoat \& Scarino, 2013: 23). This mediation of the relationships among the three makes intercultural communication competence essential in language teaching and learning.

Based on the dynamic and interactive relationships among language, cultural and identity, language teaching and learning is more than just linguistic and communicative skills, but as Byram (1997) notes to be sociolinguistic, critical cultural and political issues. Its purpose is to cultivate competent "intercultural speakers" (Byram, 2008:57) who are 
able to "enunciate his/her identity of origin rather than trying to be someone else with a different identity" (Feng, 2009:286). After reviewing three notions of multicultural, bicultural and intercultural speaker Feng concludes that, in Chinese context, where strong emphasis is put on national identity, "intercultural speaker" is the realistic objective in our bilingual education (p. 292).

\section{ICC in Language Teaching and Learning}

The concept of ICC (intercultural communication competence) origins from Hymes' (1972) Communicative Competence which emphasizes on the sociolinguistic competence of using language appropriately. Though Byram (1997) criticizes it as misleading in transferring the description of first language acquisition and communication into that of foreign language teaching and learning, the concept of sociolinguistic competence sheds light on putting FLT into a broader context, because it groups linguistic competence as one kind of cultural competence. Van Ek (1986) develops this concept into his "framework for comprehensive foreign language learning objectives" (cited in Byram, 1997:9), the six competences of which focus on not just linguistic and communication skills but the personal and social development of a learner as an individual in general education. This emphasis on sociocultural competence sets the stage for the development of future FLT models.

By downgrading the importance of linguistic competence and national difference, Gudykunst (2004) focuses on effective communication with strangers in intergroup encounters. He stresses the importance of understanding cultural differences and developing relationships with strangers. From psychological factors of communication, he presents the three components of perceived competence, namely, "motivation, knowledge and skills" (p. 233). This novel perspective of seeing intercultural communication is enlightening, though not comprehensive.

Based on the models of Van Ek and Gudykunst, Byram (1997) develops his understanding of ICC, describing in chart as "Factors in Intercultural Communication" (p. 34). In this mode, the political education and critical, cultural awareness is its core, supported by attitudes and knowledge emphasis on both home and target culture as well as skills of interpreting, relating, discovery and interaction (p. 34). This model presents comprehensively the factors involving foreign language learning and teaching from sociolinguistic, sociocultural, psychological and political aspects. It is quite illuminable especially in recognizing the importance of home culture, albeit being a framework without much description in details.

As is discussed above, in teaching and learning a foreign language, intercultural competence enjoys an essential status among other competences. And home culture is of the same importance as the target culture, if not more. There are even some scholars who maintain that there is no absolute difference when we communicate interculturally and intraculturally to stress the importance of home culture (Gudykunst, 2004). In addition, intercultural foreign language teaching is widely regarded as a fundamental part of general education. However, these well accepted ideas are contested in China, some of which are contested vehemently, which is represented by, for example, the debate on the status of English and course design of College English.

\section{DISCUSSION}

\section{A. Contest on Teaching Chinese Culture in College English Classes}

Though there is some sort of consensus reached internationally on the importance of intercultural communication in foreign language education, and it is well accepted that both the home culture and the target culture are part of the knowledge an intercultural speaker should possess (W. Baker, 2012; Byram, 1997), intercultural communication in English education in China is debated and in practice mostly ignored, not to mention the teaching of Chinese culture.

The core of the debate is on what being the fundamental objectives of college English teaching and its course system, namely, English for General Purpose (EGP) or English for Specific Purposes (ESP). As one strong advocate of ESP, Cai (2017) claims that the most important goal of English teaching in university should be cultivating students who are both professionally competent and are fairly fluent in English communication (ESP). He also believes that College English education should not belittle the instrumental role of English, because "the most significant function of a language is a tool of communication" (P. 3). He even regards the choice of an ESP course over a course like Chinese Culture as "wise", when class hours of college English is reduced to a limited 180 in two academic years (Cai, 2018).

S.R. Wang (2011), on the other hand, believes ESP, together with EGP and English for General Education (EGE), is one part of College English teaching (p. 3). He disagrees with Cai that ESP is the only way to the future development of college English teaching in all colleges and universities (Cai, 2018). S.R. Wang (2011) also states that College English teaching should help students understand Western civilization (including ways of thinking and living habits), look at Western culture and core values with a critical eye, be familiar with Chinese and foreign cultural differences, and cultivate intercultural communication skills. That's the reason why Requirements on College English Teaching (2007) define the nature of college English as "both instrumental and humanistic" (p. 3). In his "Interpretation of Guidelines on College English Teaching (2017)", S.R. Wang (2016) reiterates humanistic quality of English teaching and emphasizes on its intercultural communication, whose importance has begun to be accepted by many policy makers and shareholders (The Guideline, 2017; Zhang,2012; Gu,2016; S.R. Wang,2016; Sun,2016). 
Despite the growing recognition of ICC in English teaching in China, there are still many problems in practice. The most prominent two, according to Zhang (2012), are firstly; cultural teaching is an accessory to language teaching thus it is not systematic. Secondly, the unclear objectives and incomplete teaching content have long been a troubling issue.

\section{B. The Rationale of Involving Chinese Culture in CET}

1. The requirement of the new era

The "Chinese Culture Going Global strategy" was first put forward at The Fifth Plenary Session of the 15th Central Committee of the CPC, in 2000 (Yang, 2014). Sun Jiazheng, the then Minister of Culture, interpreted it in 2002 as:

disseminating contemporary Chinese culture by penetrating into the mainstream international society and the mainstream media, ... to establish a brand-new image of contemporary China, and build our country into an international cultural center based on Asia-Pacific and facing the whole world.

This ambitious target of "international cultural center" means well in promoting the status of Chinese culture in the world. Whereas, it is against the nature of ICC development of de-centering thus serves more as a political and ideological concept. Nevertheless, this idea then was gradually improved and developed to be a mature strategy in the Outline of the National Plan for Cultural Development in the Eleventh Five-Year Plan Period in 2006. The core of the strategy is to actively participate in international cooperation and competition by making full use of the domestic and international markets and resources so as to form an open culture pattern which may interact with foreign cultures and may promote Chinese culture to the world. The major measures taken in the field of foreign cultural exchanges include expanding foreign cultural exchanges and channels of communication, cultivating export-oriented backbone cultural enterprises, and implementing major outreaching projects.

This emphasis on culture is well acknowledged by policy makers in education, for example, the integration of intercultural communication in college English teaching is written in The Requirements (2007). Dai and Wang (2015) also stress the importance of the understanding and mastery of Chinese culture in foreign language teacher training in the context of outreaching strategy. The ultimate goal of foreign language teaching, as Zhang (2012) puts it, is to improve intercultural communication competence of emotion, attitude, knowledge and skills. Only in this way, can foreign language teaching contribute to the development of the society and satisfy individual needs in the process of globalization.

2. To keep cultural confidence

The international culture and language exchange has never been equal. Holliday (2009) believes that in cultural politics, the west "projects concepts of a culturally superior Centre-Western Self and an inferior Other onto the rest of the world" (p. 148). Hannerz (1997) claims that in cultural flow, the periphery is "more the taker than the giver of meaning and meaningful form" (p. 107). Though Chinese culture, with its profound cultural foundation, is not periphery in traditional sense; it is mostly a taker in global cultural hybridization. Liang and Zhang (2018) also express their concern about "more importing than outreaching" in language exchanging (p. 100). To keep our cultural identity in cultural exchange, and to further introduce Chinese language and culture to the world, we need to strengthen traditional Chinese cultural education, especially in intercultural language teaching classes like college English.

3. The nature of language leaning

Language learning, according to Liddicoat and Scarino (2013), is both an act of learning about the other and the self. Because when learning a language other than their mother tongues, the learner unavoidably brings "more than one language and culture to the process of meaning-making and interpretation". Therefore, "to enter other culture is to re-enter one's own" (p. 2). In other words, it is impossible to learn a foreign language or culture without taking one's own language and culture into it. The process of encountering with the other is always involving knowing, assessing, comparing with their own.

Due to the limitation of communicative language teaching, foreign language education has turned to intercultural communicative language teaching and its objective is to improve students' intercultural communication competence. When defining ICC, Byram (1997) stresses the importance of home culture in all the factors of ICC, namely, attitude, knowledge and skills:

Attitude: curiosity and openness, readiness to suspend belief about other cultures and belief about one's own. (p.50) Knowledge: of social groups and their products and practices in one's own and in one's interlocutor's country, and the general processes of societal and individual interaction. (p.51) Skills of interpreting and relating: Ability to interpret a document or event from another culture, to explain it and relate it to documents from one's own. (p.52)

Therefore, incorporating home culture into the curriculum of language teaching, especially college English teaching is not only the requirement of this era in the context of Chinese Cultural Going out Strategy but also the need to keep cultural confidence in unequal international communication. It is also decided by the nature of language learning.

\section{Challenges and Suggestions}

1. The complexity of teaching culture: what and how to teach?

In their review of culture and language learning, Byram \& Feng (2004) conclude that the new emphasis for language teachers and researchers is "cultural teaching and researching as well as ICC in language teaching" (p. 164). The importance of integrating intercultural competence into English learning and teaching has been widely recognized, but one of the challenges remains as "moving from recognition to the development of practice" (Liddicoat \& Scarino, 
2013:1). In language teaching and learning, culture has been understood as national attributes, societal norms, symbolic systems and practices, which reveal the complexity of teaching culture (p. 17). Therefore, the primary question is "what and how to teach".

In the context of Outreaching Strategy, it becomes popular to involve Chinese culture in language classes to improve students' ICC. However, many teachers mistakenly believe that introducing some cultural knowledge in class is intercultural education (Zhang, 2012). This misconception is common. For example, in my university, teaching Chinese culture for most teachers equals to translation (C-E) of short passages on Chinese customs, foods, places, festivals, traditions, arts and so forth. The enthusiasm stems from the assess requirement in College English Test band 4 and 6 (CET-4\&6). Though this test-driven action may help students learn some knowledge of Chinese culture in English, it may not change their attitudes on home and target culture and it may not help them improve the skills to act interculturally.

The effective intercultural language teaching is more than just teaching the knowledge about home and target culture, but as Feng (2009) puts it "bring two or more cultures into relationship" and "mediate among different values, beliefs and behaviours", finally become "intercultural speakers" (p. 286). For example, when discussing gender inequality in job hunting, teachers may guide students to find gender prejudice in other fields of the society both at home and abroad. The choice of the sub-topics of gender inequality may include: Marriage, economy, politics, entertainment industry, language, workplace, health care and military. Then teachers may encourage students to compare this issue in different regions of China (e.g. north vs. south; city vs. countryside) and in the world (Not necessarily English speaking countries, but other regions and countries like: Europe, India, Middle East, etc.) In this way, critically comparing Chinese culture with other cultures in English is helpful in improving students ICC, because it provides students with the opportunity to deal with the problems or topics relevant to their lives.

However, there is the danger of going to another extreme by focus solely on Chinese culture in English class. Yu and Van (2018) have implemented action research in English reading class by asking students to find different English texts from various media about one topic (e.g. Beijing Opera; Yin and Yang). They believe, by seeing from different perspectives of a cultural issue, the students will "become more cautious in speaking of the Chinese or any other culture for that matter" (p. 369). I know some teacher who is also doing the similar project in teaching mostly Chinese culture in English class. Nevertheless, the benefit of improving students' ICC is limited by discussing a topic solely on one's home culture, despite the great variety of it. That's why Cui (2009) reminds us "the moderate principle" which means we cannot change the nature of English courses. Byram (1997) states that comparative studies are helpful in raising awareness of the complex process of social interactions. This comparison, I believe, refers to international cultures, that is, between home culture and other cultures.

2. Should we have textbooks?

Culture seems to be too huge a topic to be organized in a textbook. In addition, as beliefs, meanings and behaviours which are dynamic and individualized, it is also believed impossible to do so. There are also the issues of representativeness of different social groups. All of these are the reasons many scholars do not advocate the compiling of cultural textbooks, which they believe only will make culture static and prejudiced (Byram, 1997). Instead, only framework of guidelines is provided.

However, as a college English teacher myself, I believe it is of vital importance to have intercultural English textbooks for College English teachers in China. And with the reminding of the complexity of culture and suggestions on how to use these textbooks wisely in the preface, it will be quite beneficial to both the teachers and students. The reason lies, firstly, in the disparity of teachers' linguistic levels as well as their cultural awareness in different universities and regions. High quality textbooks which are updated regularly may serve as a valuable training material and reference to the teachers who have limited resources. As is shown in Xu's survey, 63.4\% teachers and 74.6\% students use textbook as a main source to teach and learn English (2008).

Secondly, it is an efficient way of getting quick information. There are indeed a large amount of resources for intercultural English learning, including written texts, videos, audios, music, multimedia, websites, apps and so forth. But college English teachers in China are usually burdened with heavy teaching tasks of about 14 periods of classes a week on average. It would be too demanding for them to collect information from various media and organize them into their class all by themselves. On the other hand, with a well-organized textbook, it will be far more efficient and time-saving.

Present college English textbooks, whereas, have focused mostly on linguistic skills and introduction of culture of English speaking countries, with little or no introduction of home culture or comparison of the two. The last couple of years have witnessed some progress in involving home culture, but it is far from satisfactory. For example, in the textbook of "New Progressive College English" (Li, 2017), one reading passage about the discussed topic in Chinese context is added at the end of each unit. Nevertheless, there is no guidance or suggestion on how to use this passage in the "Teacher's manual" ( $\mathrm{Ji}, 2017)$, such as how to organize class activities to compare home and target culture, how to help the students to improve their intercultural awareness and ICC or how to assess students' intercultural learning results. Instead, the suggested teaching plan is all about linguistic skills and the rest parts are language focus and keys to exercises. What's worse, in "Teaching Goals", home culture or ICC are not mentioned at all. This neglect reveals the textbook compilers' real attitude: the objectives of English teaching are still mainly to achieve linguistic progress. It 
shows the complexity and difficulty of involving intercultural communication effectively, even though the importance of which is well recognized.

3 . Are the teachers ready?

Byram \& Manuela (2018) believe language educators should consider their "important role and responsibility" in educating university students ready to "live and thrive in multilingual and multicultural societies, including their own" (p. 141). Gu (2016) also states it is more demanding to language teachers after the shift of EFL to intercultural communicative language teaching (ICLT), because the teachers should not only be interculturally competent themselves, but also be equipped with the methodologies of cultivating students' ICC.

However, some educators assume that when they teach a language, they automatically teach culture or even intercultural competence (Byram \& Manuela, 2018). This misunderstanding is universal. Gu's nation-wide survey on EFL teachers' perception and practice of assessment of ICC in China shows they are not ready. In spite of the teachers' realization of the importance of ICC and willingness of integrate intercultural language teaching in the curriculum, the result of the survey reveals the secondary status of ICC in language learning and the insufficient and even inaccurate understanding of ICC from EFL teachers themselves (2016:263).

It is a pity that the available teacher trainings currently are mostly in fields of linguistic skills, pedagogy and teaching research; few are about intercultural communication competence; still fewer about the critical comparison between home and target culture. Therefore, such ICC training to intercultural language teachers is urgent, and this void of teacher training needs to be filled.

4. How to assess?

Assessment is the most conflicting and obscure part of ICC, as Gipps (1994) notes that "Assessment is not an exact science" (p. 167) Although Byram (1997) develops assessment criteria of ICC in five aspects of his model, he admits that all aspects of ICC cannot be "quantified and reduced to a single score" (p. 111). That is the main reason why ICC is not directly included in the assessment of any standard language tests. Therefore, in the context of utilitarian education, if it is not tested, it is not important. Though, the importance of assessment is recognized, for example, Sun (2016) emphasis the necessity of integrating assessment of ICC into the English language evaluation system, he does not elaborate on how.

At present, the only Chinese culture-related test in national level is translation (C-E) in CET-4 \& 6, which may stimulate some motivation of involving knowledge of Chinese culture in college English class, but it is not the test of ICC. This assessment of linguistic skills and knowledge of Chinese culture is typical. In the case study of testing college students' ability to describe Chinese culture in English, Zhang \& Zhu (2002) ask students to either write or talk about Chinese food, customs or historical sites. It in essence is similar to the test of translation in CET-4\&6; it is not the test of ICC either. Due to the guiding function evaluation system plays in education, this phenomenon is representative. For example, the only assessment of teaching Chinese culture in college English class in our university is also the testing of translation skills and knowledge CET-4\&6 requires. Therefore, there leaves much to be expected in assessment system of ICC in college English courses.

\section{CONCLUSION}

English, as a lingua franca, teaching in an additive context in China generally won't cause serious identity confusion in most cases as some may have worried. However, it's still necessary to cultivate students with traditional Chinese culture in college English class in the process of global culture hybridisation. This is decided by the nature of language teaching and learning as home culture is an indispensable part of one's ICC. It is also the requirement of the new era in the context of Outreaching Strategy. What's more, it helps to keep our cultural confidence in intercultural communication. Although there are some opponents who prioritize the linguistic and instrumental value of English, the importance of intercultural language teaching and learning has been recognized by most scholars and policy makers. Nevertheless, in practice, college English teaching is still mostly focusing on linguistic skills and various problems exist in integrating home culture in college English curriculum. All of these prevent the effectiveness of improving students' ICC, but the difficulties are not invincible. By given the opportunity to compare their home culture with that of the others, students may greatly develop their intercultural awareness and ICC. And that is one of the most important objectives of college English education.

\section{REFERENCES}

[1] Baker, C. (2011). Foundations of bilingual education and bilingualism (5th ed.). Bristol, UK: Multilingual Matters.

[2] Baker, C. \& Wright, W (2017). Foundations of Bilingual Education and Bilingualism (6th ed.). Bristol, UK: Multilingual Matters.

[3] Baker, W. (2012). From cultural awareness to intercultural awareness: culture in ELT. ELT Journal, 66(1), 62-70.

[4] Byram, M. (1997). Teaching and assessing intercultural communicative competence. Clevedon: Multilingual Matters.

[5] Byram, M. \& Feng, A.W. (2004). Culture and language learning: teaching, research and scholarship. Language Teaching, 37(3), 149-168.

[6] Byram, M. (2008). From foreign language education to education for intercultural citizenship: Essays and reflections. Languages for intercultural communication and education. Clevedon. 
[7] Byram, Michael, \& Wagner, Manuela. (2018). Making a Difference: Language Teaching for Intercultural and International Dialogue. Foreign Language Annals, 51(1), 140-151.

[8] Bourdieu, P. (1991). Language and symbolic power. edited and introduced by John B. Thompson: Cambridge, Mass.: Harvard University Press.

[9] Cai, J.G. (2017). Review of Chinese Tertiary English Education: Failure and Lessons. Journal of Northeast Normal University: Philosophy and Social Sciences, 5, 1-7.

[10] Cai, J.G. (2018). ESP in China Revisited: Beliefs and Concepts: Reflection of FLT since China's Reform and Opening up in 1978). Foreign Languages Research, 35(02), 42-47.

[11] Cui, G. (2009). The Infiltration of Chinese Culture in College English Teaching. China University Teaching, 03, 86-89.

[12] Dai, W.D. \& Wang X.M. (2015). The Development Strategy of Foreign Languages and Literatures in China under the Background of "Outreaching Strategy". Journal of PLA University of Foreign Languages, 38(04),1-11.

[13] Feng, A. W. (2007). Intercultural space for bilingual education. In A. W. Feng (Ed.), Bilingual education in China (pp. 259-286). Clevedon, UK: Multilingual Matters.

[14] Feng, A. W. (2009). Identity, "acting interculturally" and aims for bilingual education: an example from China. Journal of Multilingual and Multicultural Development, 30(4), 283-296.

[15] Feng, A. W. (Ed.). (2011). Introduction: The Apex of 'the Third Wave'---English language across Great China. In A.W. Feng (eds.), English language education across Greater China (pp. 1-20). Bristol, UK: Multilingual Matters.

[16] Feng, A. W. \& Adamson, B. (2015). Contested Notions of Bilingualism and Trilingualism in the People's Republic of China. In W. E. Wright, S Boun \& O. Garcia (eds.), The Handbook of Bilingual and Multilingual Education (pp. 484-494). John Wiley \& Sons, Inc.

[17] Garcia, O. (2009). Bilingual Education in the 21st Century. Chichester, UK: John Wiley \& Sons.

[18] Gil, J., \& Adamson, B. (2011). The English language in China: A sociolinguistic profile. In A. Feng (Eds.), English language education across Greater China (pp. 23-45). Bristol, UK: Multilingual Matters.

[19] Gipps, C. (1994). Beyond Testing: Towards a Theory of Educational Assessment. London: Falmer Press.

[20] Gu, X. (2016). Assessment of Intercultural Communicative Competence in FL Education: A Survey on EFL Teachers' Perception and Practice in China. Language and Intercultural Communication, 16(2), 254-273.

[21] Gudykunst, W. B. (2004). Bridging differences: effective intergroup communication (4th ed.). Thousand Oaks, Calif.: Sage Publications.

[22] Hannerz, U. (1997). Scenarios for Peripheral Cultures. In A.D. King (Ed.), Culture, Globalization and the World-system (pp. 107-128). Minneapolis, US: University of Minnesota Press.

[23] Holliday, A. (2009) The role of culture in English language education: key challenges. Language and Intercultural Communication, 9(3), 144-155.

[24] Hu, Guangwei. (2008). The Misleading Academic Discourse on Chinese-English Bilingual Education in China. Review of Educational Research, 78(2), 195-231.

[25] Hymes, D. (1972). On communicative competence. In J.B. Pride and J. Holmes (eds) Sociolinguistics. Harmondsworth: Penguin.

[26] Ji,P.Y. (2017). New Progressive College English integrated course 1 - teacher's manual. Shanghai, China: Shanghai Foreign Language Education Press.

[27] Kachru, B. B. (2009). World Englishes and cultural wars. In Kachru, B. B., Kachru, Y., \& Nelson, C. L. (Ed.), The handbook of world Englishes. (pp.446-471) Chichester: Wiley-Blackwell.

[28] King, A. D. (1997). Culture, globalization, and the world-system: contemporary conditions for the representation of identity. U.S. Minn.: University of Minnesota Press.

[29] Li, M.H. (2017). New Progressive College English integrated course 1 -student's book. Shanghai, China: Shanghai Foreign Language Education Press.

[30] Liang, S. G. \& Zhang, Y. J. (2018). Language Strategic Planning and Policy Practices for the "Belt and Road" Initiative. People's Forum - Academic Frontiers, 10, 98-105.

[31] Liddicoat, A. \& Scarino, A. (2013) Intercultural Language Teaching and Learning. UK: Wiley-Blackwell.

[32] Ministry of Education (2007). Requirements on College English Teaching, Beijing, China.

[33] Sun, Y.Z. (2016). Foreign Language Education and Cultivation of ICC. Chinese Foreign Language, 13(03), 1+17-22.

[34] Wang, S.R. (2011). Some Thoughts on College English Teaching in China. Foreign Language Teaching Theory and Practice, $01,1-5$.

[35] Wang, S.R. (2016). Interpretation of 'the Guidelines on College English Teaching'. Foreign language world, 03, 2-10.

[36] Wang, X. (2018). Some Considerations about "Chinese Cultural Going Global” Strategy). Journal of Hangzhou Normal University: Humanities and Social Science, 40(05), 124-128.

[37] Xu, K.Q. (2004). Loss of Chinese culture deserves attention in the bilingual education craze. Foreign Language Education, 03, 86-89.

[38] Xu, L.F. (2008). Incorporating Chinese culture into college English teaching in China. Zhejiang University, p36

[39] Yang, L.Y. (2014). The Significance of the "Outreaching Strategy" in the New Period. People's Forum, 23, 186-188.

[40] Yu, Q. \& Van Maele, J. (2018). Fostering Intercultural Awareness in a Chinese English Reading Class. Chinese Journal of Applied Linguistics, 41(3), 357-374.

[41] Zhang, H.L.(2012). Foreign language teaching guided by intercultural education: Past, present and future. Foreign Language World, 02, 2-7.

[42] Zhang, W. M. \& Zhu, H.M. (2002). Chinese Culture in College English Teaching. Research on Education Tsinghua University, s1, 34-40. 


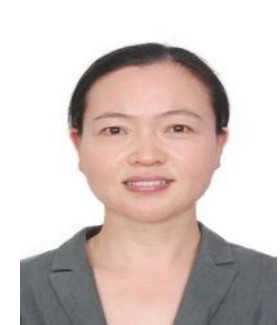

Xiaomei Zhu was born in Jiangsu Province, China in February 1977. She is pursuing a Professional Doctorate Degree of Education in University of Nottingham, Ningbo, China. She holds an M.A. in English literature from Shanghai International Studies University, Shanghai, China.

At present, she is a lecturer teaching College English in Sino-German Institute of Design and Communication, Wanli University, Zhejiang, China. Her published articles include: [1] Xiaomei Zhu (2004). A Study on Teaching Reading in College--- Two Ways of Improving Reading. Journal of Wanli Universit.17, 164-166 [2] Xiaomei Zhu (2015). The Feature and Strategy of Journalistic Translation. Journal of Test Weekly. G4, 29-31 [3] Xiaomei Zhu (2017). The Study of Teaching College English Reading Based on the Teaching Platform of Moodle. Journal of Qiannan Normal University for Nationalities. 37.3, 64-68. Her research interests are intercultural language teaching and pedagogy. 